\title{
C5a activation by monosodium urate crystals: effect of adsorption of serum and polymorphonuclear leucocyte homogenate
}

\author{
A. D. WOOLF AND G. S. PANAYI \\ From the Departments of Medicine and Rheumatology, Guy's Hospital Medical School, London SE1 9RT
}

Acute gout is characterised by intermittent episodes of acute inflammation of joints separated by symptom-free periods. This acute inflammatory response is not solely dependent on the presence of intra-articular monosodium urate crystals (MSU), as they can be found in asymptomatic joints, and the control mechanisms, particularly of the switch off, are unresolved. MSU crystals bind a wide variety of proteins, especially $\mathrm{IgG}^{1}$ but also cytoplasmic and lysosomal constituents. ${ }^{2}$ Adsorbed IgG may promote complement activation ${ }^{3}$ and increase polymorphonuclear leucocyte (PMN) lysosomal enzyme release. ${ }^{4}$ Alterations in the crystal coating subsequent to phagocytosis by PMNs may thus reduce or abrogate their phlogistic properties. In addition, it is possible that MSU crystals cause local depletion of pro-inflammatory factors by adsorption and thereby modify the inflammatory response.

MSU crystals activate serum complement, leading to the generation of the potent chemotaxin $\mathrm{C} 5 \mathrm{a},{ }^{5}$ and a principal activity of PMN in response to acute inflammation is chemotaxis. We have, therefore, looked at the ability of MSU to generate chemotactic activity in serum and the effect of serum coating and PMN homogenate on this ability. We also looked at the ability of these crystals to activate serum depleted by adsorption with MSU.

Synthetic crystals of MSU were coated with normal human serum at 5 $\mathrm{mg} / \mathrm{ml} 4^{\circ} \mathrm{C}$ for $60 \mathrm{~min}$. Coated or plain MSU crystals were then incubated with normal human serum or adsorbed serum for $4 \mathrm{~h}$ at $37^{\circ} \mathrm{C}$, with or without having been previously incubated for
60 min at $37^{\circ} \mathrm{C}$ in a PMN homogenate. Adsorbed serum was the supernatant left after coating the MSU crystals. PMN homogenate was prepared by dextran sedimentation of heparinised venous blood, RBC lysis, freeze-thawing and sonicating a suspension of $2 \times 10^{7} \mathrm{PMN} / \mathrm{ml}$. MSU crystals were washed twice with MSU saturated sodium phosphate 0.0001 mmol buffer, $\mathrm{pH} 7 \cdot 4$, between all stages, and all incubations performed with constant mixing. Chemotactic activity was assayed by a modified agarose technique, ${ }^{6}$ all samples being heat inactivated at $56^{\circ} \mathrm{C}$ for $30 \mathrm{~min}$. Migration distance was taken as the average distance travelled by the five most rapidly travelling cells towards the test well.

Coated MSU crystals were as capable of activating normal human serum and adsorbed serum as plain crystals. Comparing activation of adsorbed and non-adsorbed serum, significantly less chemotactic activity was generated in adsorbed than in normal human serum by coated MSU crystals in four of five experiments ( $p$ $=0.01$ ) and by plain MSU crystals in two of five experiments $(p=0 \cdot 01)$.

Generation of chemotactic activity in fresh serum by plain or coated MSU was unaffected by treatment with PMN homogenate, but the activation of adsorbed serum by coated MSU crystals was significantly increased after treatment with PMN homogenate in two of three experiments $(p=0 \cdot 01)$.

Cell homogenate showed no significant activation of fresh or adsorbed serum in solution.

Adsorbed serum showed normal generation of chemotactic activity with zymosan $\left(1 \mathrm{mg} / \mathrm{ml} 30 \mathrm{~min} 37^{\circ} \mathrm{C}\right)$ compared with normal human serum. Using a functional assay for C5a we found that coating MSU crystals in serum, where IgG is the principal adsorbed molecule, ${ }^{1}$ had no effect on the activation of $\mathrm{C} 5 \mathrm{a}$.

The effect of treating coated MSU crystals with PMN homogenate in increasing the generation of chemotactic activity in adsorbed serum cannot be attributed to any direct activation by PMN homogenate and must be due to changes in the MSU coating.

It is interesting that adsorbed serum when exposed to coated MSU crystals failed to generate as much chemotactic activity as similarily treated fresh serum. As the coated crystals used to activate the adsorbed serum in these experiments were the same as those used in the initial adsorption, then no factors should have been depleted from this system. This suggests that binding of serum components to MSU crystal surfaces may produce changes in the adsorbed material that impairs the generation of chemotactic activity. This may be an important factor in the self limitation of acute gouty arthritis.

\section{References}

1 Kozin F, McCarty D J. Protein binding to monosodium urate monohydrate, calcium pyrophosphate dihydrate, and silicon dioxide crystals. I. Physical characteristics. J Lab Clin Med 1977; 89: 1314-25.

2 Ginsberg M H, Kozin F, Chow D, May J, Skosey J L. Adsorption of polymorphonuclear leukocyte lysosomal enzymes to monosodium urate crystals. Arthritis Rheum 1977; 20: 1538-42.

3 Hasselbacher P. C 3 activation by monosodium urate monohydrate is enhanced by surface IgG. Arthritis Rheum 1979; 22: 620 . 
4 Kozin F, Ginsberg M H, Skosey J L. Polymorphonuclear leukocyte responses to monosodium urate crystals: modification by adsorbed serum proteins. $J$ Rheumatol 1979; 6: 519-26.

5 Russell I J, Mansen C, Kolb L M, Kolb W P. Activation of the fifth component of human complement (C5) induced by monosodium urate crystals: $\mathrm{C} 5$ convertase assembly on the crystal surface. Clin Immunol Immunopathol 1982; 24: 239-50.

6 Nelson R D, Quie P G, Simmons R L. Chemotaxis under agarose: a new and simple method for measuring chemotaxis and spontaneous migration of human polymorphonuclear leukocytes and monocytes. J Immunol 1975; 115: $1650-6$.

\title{
Inflammatory effect of aluminium phosphate
}

\author{
P. NETTER, J. L. DELONGEAS, G. FAURE, P. BOZ, D. B URNEL, J. L. FOL I GUET, \\ M. F. KESSLER, R. J. ROYER, A. GA UCHER
}

From the Travail de la Clinique Rhumatologique, des Laboratoires de Pharmacologie, d Anatomie pathologique, de Chimie et d'Histologie, et du Service de Néphrologie, Faculté de Médecine de Nancy, Université de Nancy I, 54500 Vandoeuvre les Nancy, France

Microcrystalline-induced arthritis is known to occur in patients undergoing haemodialysis for chronic renal insufficiency. The following microcrystals have been implicated so far in these inflammatory phenomena: apatite, calcium pyrophosphate dihydrate (CPPD), and sodium monourate.

In preliminary study, ${ }^{12}$ using scanning electron microscopy (SEM) and wavelength dispersive microanalysis (WDM), we found aluminium deposits associated with phosphate in synovial tissue from a patient undergoing haemodialysis because of chronic renal insufficiency, who had been taking aluminium hydroxide for five years. Aluminium concentrations measured with a sensitive and reproducible pulse polarography method were raised in the synovial fluid $(87 \mu \mathrm{g} / \mathrm{l})$, synovial tissue $(3.7$ and $2.2 \mu \mathrm{g} / \mathrm{g}$ wet weight) and in the cartilage $(22 \mu \mathrm{g} / \mathrm{g}$ wet weight) compared with controls: synovial fluid: $10 \cdot 8 \pm 5 \mu \mathrm{g} / \mathrm{l}(\mathrm{n}=6)$, synovial tissue: $0 \cdot 8 \pm 0 \cdot 2 \mu \mathrm{g} / \mathrm{g}(\mathrm{n}=4)$, cartilage: $8 \cdot 31 \pm 2 \cdot 0 \mu \mathrm{g} / \mathrm{g}(\mathrm{n}=4)$. Transmission electron microscopy (TEM) revealed electron dense material of microfibrillar appearance in lysosomes of macrophagic synovial cells.

In a second part we developed experimental models to appreciate the prophlogistic properties of aluminium phosphate using two different animal models: (a) paw oedema after subcutaneous injection in the rear foot pad of Sprague Dawley rats and $(b)$ experimental arthritis after intra-articular injection in rabbits.

Tribasic aluminium phosphate was compared to calcium hydrogen phosphate dihydrate previously found during destructive chondrocalcinosis in humans ${ }^{4}$; natural diamond powder and lambda carrageenan were chosen as negative and positive controls.

In the first model, inflammation induced by aluminium phosphate reached its maximum as soon as 15-30) min after injection but lasted only 24 hours. The response to calcium hydrogen phosphate dihydrate was only minor whereas carregeenaninduced inflammation appeared after two hours but was far greater and lasted mored than 24 hours.

The second experimental proceeding was used to evaluate the histological consequences of the injection of these compounds on synovial tissue and cartilage. Rabbits were injected in the knee joints every day for three days. Aluminium phosphate can induce, like carrageenan, inflammatory lesions of the synovial tissue and erosive damage of the articular cartilage. With TEM, lysosomal inclusions of phagocytosed material with microfilaments were seen. Through SEM coupled with a wavelength dispersive microprobe analysis, aluminium associated with phosphate was found in cellular elements. These features are similar to those observed in the patient in our preliminary study and those described in cerebral tissue from patients with aluminium intoxication.

The inflammatory effect demonstrated in this study suggests that in addition to apatite, calcium pyrophosphate dihydrate and sodium monourate, aluminium compounds could play a part in clinical manifestations observed in patients with chronic renal insufficiency undergoing haemodialysis and receiving aluminium gels.

\section{References}

1 Netter P, Burnel D, Hutin M F, Kessler $M F$. Faure G. Aluminium in joint tissues of patient taking aluminium hydroxide. Lancet 1981; i: 1056-7.

2 Netter P. L'aluminium dans l'os, le cartilage, la membrane synoviale et le liquide synovial. University of Nancy, Nancy, 1980. Thesis.

3 Royer R J, Delongeas J L, Netter P, et al. Inflammatory effect of aluminium on rat paws. Pathol Biol (Paris) 1982; 30: 211-5.

4 Faure G, Netter P, Malaman B. Steinmetz J. Monocrystalline calcium hydrogen phosphate dihydrate in destructive arthropathies of chondrocalcinosis. Lancet 1977; ii: 142-3. 